\title{
Formal clinical primary health care training. Does it make a difference?
}

\author{
GMC Louwagie, MBChB, DHM (UFS), DTrop Med (Belgium), Registrar, Dept of \\ Community Health, UFS \\ MO Bachmann, MBChB, DOH, MSc, PhD, FFCH(SA), MFPHM (UK), Head, Dept of \\ Community Health, UFS \\ M Reid, B Cur (UP), BA Cur (UNISA), DPHC (UFS), Senior Professional Nurse Training \\ Mangaung Municipality
}

\section{Abstract}

Throughout South Africa, primary clinical care is mainly provided by nurses.

In line with this, most professional nurses of the former Bloemfontein local authority completed a one year "Advanced Diploma in Health Assessment, Diagnosis and Treatment" course at the University of the Free State. This study aimed to compare the clinical competencies of nurses who obtained this diploma with those who did not. The primary objective was to assess the clinical management of one chronic and one acute disease (diabetes mellitus and acute respiratory tract infections in adults, respectively) for these two groups of nurses. Relationships between quality of care and nurses " and clinics“ characteristics were also examined since they could be predictors of quality of care, independent of the influence of training.

We reviewed records of 286 consecutive visits for adults with diabetes and 293 consecutive visits for adults with an acute respiratory tract infection (ARTI). Nurses completed questionnaires on nurse characteristics, while the researchers obtained the information about the clinics. Recording of important generic (for ARTIs) and diseasespecific steps (for diabetes) in patient management were assessed. Results for patients of "trained"and"nontrained" professionals were compared and adjusted for nurses`, clinics` and patients' characteristics.

There was generally little evidence of patients being thoroughly managed.

Formal training was marginally associated with better care for ARTIs $(p=0.06)$ but not for diabetes $(p=0.47)$. Other factors associated with more thorough care were years of experience in curative primary health care $(p=0.006)$ and additional nursing degrees for ARTIs $(p=0.03)$ and the presence of enrolled or assistant nurses at the clinic for diabetes $(\mathrm{p}=0.06)$. Fixed clinics generally performed better than mobile and satellite clinics.

\section{Abstrak}

Primêre kliniese sorg word dwarsdeur Suid Afrika hoofsaaklik deur verpleegkundiges verrig. Die meerderheid van die verpleegkundiges by die Bloemfonteinse plaaslike owerheid in die Vrystaat, het reeds 'n "Gevorderde Universiteitsdiploma in Primêre Kliniese Gesondheidsorg" kursus by die Universiteit van die Vrystaat voltooi.

Daar word met hierdie studie beoog om die kliniese bevoegdhede van verpleegkundiges wat die diploma verwerf het, te vergelyk met dié wat dit nie verwerf het nie. Die primêre doelwit was om die kliniese hantering van een kroniese en een akute siekte (suikersiekte en akute lugwegontsteking in volwassenes) van die twee groepe verpleegkundiges waar te neem. Die verhouding tussen die verpleegsters en klinieke se kenmerke en die kwaliteit van die sorg is ook ondersoek, aangesien hulle voorspellers van kwaliteit van sorg kan wees, onafhanklik van die invloed van opleiding.

Ons het rekord-evaluering gedoen van 286 opeenvolgende besoeke vir suikersiekte en 293 opeenvolgende besoeke vir volwassenes met akute lugwegontsteking (ALWO). Die verpleegkundiges het die vraelys vir die verpleegkundige se besonderhede voltooi en die navorsers het die inligting van die klinieke verkry. Belangrike generiese (vir die ALWO) en siekte-spesifieke stappe (vir suikersiekte) in die hantering van pasiënte is geassesseer.

Die resultate vir die "opgeleide " en die "nie-opgeleide" professionele verpleegkundiges is vergelyk en aangepas vir verpleegkundiges, klinieke en pasiente se kenmerke. Daar was oor die algemeen min bewyse van deeglike hantering van pasiënte. Formele opleiding was matig geassosieerd met beter sorg vir ALWO $(p=0.06)$ maar nie vir suikersiekte nie $(\mathrm{p}=0.47)$. Andere faktore wat bygedra het tot beter sorg in ALWO was die getal jare ervaring in kuratiewe primêre gesondheidsorg $(p=0.006)$ en bykomende verpleegkundige grade $(p=0.03)$. Ingeskrewe of assistant-verpleegkundiges in die kliniek het weer bygedra tot beter sorg vir suikersiekte $(p=0.06)$. Vaste klinieke het oor die algemeen beter as mobiele en satelliet klinieke gepresteer. 


\section{Introduction}

South Africa has adopted the primary health care (PHC) approach, with nurses as the cornerstone for the delivery of first level clinical services. Training approaches vary widely and effectiveness of training for PHC is not well known.

The Mangaung local authority in the Free State province manages 22 clinics in the Bloemfontein area, which are nurse-run and fulfil preventative and curative functions. The role of doctors is limited to initiation of certain treatments and review of reason for seeking health care and due to their wide range of manifestations, allow for an assessment of basic clinical knowledge and skills. A recent controlled before-after intervention study showed a significant increase in prescribing outcomes and medicine utilization after a primary care drug therapy course for acute minor ailments in the Goldfields area in the Free State (Rothmann JC, Gerber JI, Venter OM, Steyn HS, de K Monteith JL 2000:47). A Soweto study compared nurses‘ and pediatricians" competence in the clinical detection of important respiratory signs in children with respiratory complaints (Irwig LM , Porter B, Wilson TD, Saunders LD, Wagstaff LA,

\section{Table 1: Characteristics of patients managed by trained and untrained nurses}

\begin{tabular}{lccc}
\hline & Trained & Untrained & P- value \\
\hline $\begin{array}{l}\text { Acute Respiratory Tract } \\
\text { Infections }\end{array}$ & $(\mathrm{N}=220)$ & $(\mathrm{N}=73)$ & \\
Age Median (IQR) & $36(26-48)$ & $34(21-44)$ & $0.12^{*}$ \\
Sex No (proportion in \%) & & & \\
Female & $111(50)$ & $43(59)$ & $0.28^{* *}$ \\
Male & $73(33)$ & $17(23)$ & \\
Unknown & $36(16)$ & $13(18)$ & \\
Diabetes & & & \\
Age Median (IQR) & $(\mathrm{N}=195)$ & $(\mathrm{N}=91)$ & \\
Sex No (proportion in \%) & $58(50-67)$ & $58(49-68)$ & $0.87^{*}$ \\
Female & & & \\
Male & $120(61)$ & $52(57)$ & $0.73^{* *}$ \\
Unknown & $58(30)$ & $29(32)$ & \\
Blood glucose value Mean (SD) & $17(9.0)$ & $10(11)$ & \\
Systolic BP Mean (SD) & $10(4.8)$ & $10(5.7)$ & $0.68 \#$ \\
Diastolic BP Mean (SD) & $143(22)$ & $147(23)$ & $0.21 \#$ \\
Diabetes type No (proportion in \%) & $(\mathrm{N}=189) \# \#$ \\
Oral & $130(69)$ & $91(14)$ & $0.52 \#$ \\
Insulin & $58(31)$ & $64(70)$ & $0.40 * *$ \\
Combination & $1(0.5)$ & $25(27)$ & \\
\hline
\end{tabular}

* Wilcoxon ranksum test

$* * \chi^{2}$ test

$\# \mathrm{t}$ test

\# excluding patients with unknown diabetes type

referred cases. With the introduction of the new policy on curative care in 1995, the majority of the professional nurses of these clinics attended a one year part-time course in primary health care at the School of Nursing at the University of the Free State (UFS). The course consisted of a full day's training on a weekly basis. Subjects taught included general diagnostic and therapeutic skills as well as common clinical conditions such as respiratory tract infections and diabetes. The effectiveness of this training has not been independently evaluated.

In this audit we compared the clinical competencies of nurses who completed a one year formal training in primary health care at the School of Nursing of the UFS with those who did not. The primary objective was to assess the clinical management of one chronic and one acute disease (diabetes mellitus and acute respiratory tract infections in adults, respectively) for these two groups of nurses. Relationships between quality of care and nurses ' and clinics " characteristics were also examined since they may be independent predictors of quality of care and could confound the relationship between training status and quality of care.

Acute respiratory tract infections in adults are an important
Liesch N, Reinach SG, Makhaya MS, Gear JSS, 1985:92-95). However, these studies did not investigate the management of acute respiratory tract infections in adults nor was formal postgraduate training evaluated.

Diabetes is a common condition in South Africa affecting over a million adults (Mash B \& Levitt NS, 1999:123). It is a condition where a systematic approach is needed to monitor glucose control and for early detection of complications. Knowledge, attitudes and practices with regard to diabetes management by nurse clinicians have been studied widely in South Africa (Daniels AR, Patel M, Biesma R, Otten J, Levitt NS, Steyn K, Martell RS, Dick J Jan 2000. Daniels AR, Biesma R, Otten J, Levitt NS, Steyn K, Martell R, Dick J Dec 2000 . Goodman GR, Zwarenstein MF, Robinson II, Levitt SL 1997. Levitt NS, Bradshaw D, Zwarenstein MF, Bawa AA, Maphumolo S1997, Mash B \& Levitt NS 1999). In none of the studies was the association between quality of care and formal PHC training of professional nurses explored. 


\section{Design}

We performed a cross sectional analytical study at all 22 Bloemfontein local authority clinics that render curative primary health care services. Individuals were thus not followed over time, but exposures and outcomes were evaluated once.

\section{Population and sample}

All professional nurses whose main task was clinical patient management at the time of the study were invited to participate (this was a total of 38 trained and 13 untrained nurses).

The patient population comprised all patients seen with a diag-
Confidentiality was ensured by using codes for the nurses, patients and clinics.

\section{Measurement}

The measurement tools consisted of patient record review forms for the assessment of clinical care and questionnaires for the clinic and nurse variables. Variables assessed for diabetes were the recording of weight, blood pressure, diabetic and other symptoms, clinical and foot examination, blood glucose level, referral for high blood glucose, urine test, eye clinic referral and relevant health education (adapted from Daniels et al. January 2000 and from Mash \& Levitt , 1999).

\section{Table 2: Acute Respiratory Tract Infections: Proportion (\%) of patients that had items recorded}

\begin{tabular}{|c|c|c|c|c|}
\hline & $\begin{array}{c}\text { Patients of all } \\
\text { nurses } \\
(\mathrm{N}=293) \\
\end{array}$ & $\begin{array}{c}\text { Patients of 'trained' } \\
\text { nurses } \\
(\mathrm{N}=220) \\
\end{array}$ & $\begin{array}{c}\text { Patients of } \\
\text { 'untrained" nurses } \\
(\mathrm{N}=73)\end{array}$ & $\begin{array}{c}\text { P-value for } \\
\text { difference } \\
\text { between groups }\end{array}$ \\
\hline Main complaint & $55 \%$ & $59 \%$ & $44 \%$ & 0.025 \\
\hline General appearance & $23 \%$ & $21 \%$ & $27 \%$ & 0.29 \\
\hline Temperature & $11 \%$ & $10 \%$ & $12 \%$ & 0.66 \\
\hline Diagnosis & $28 \%$ & $30 \%$ & $21 \%$ & 0.12 \\
\hline Number of drugs & 2 & 2 & 2 & $0.90^{\star \star}$ \\
\hline Antibiotics & $65 \%$ & $66 \%$ & $63 \%$ & 0.67 \\
\hline Referral doctor or hospital & $5 \%$ & $4 \%$ & $8 \%$ & 0.22 \\
\hline Health education or advise & $27 \%$ & $28 \%$ & $25 \%$ & 0.54 \\
\hline Further investigation & $13 \%$ & $13 \%$ & $14 \%$ & 0.93 \\
\hline
\end{tabular}

* $\chi^{2}$ test, Fisher exact (for pulse and referral).

** Wilcoxon ranksum test

nosis of diabetes or with acute respiratory tract infection (ARTI) symptoms . For diabetes, all follow-up visits were included. ARTIs were defined as newly diagnosed acute upper or lower tract infections or symptoms in patients over the age of 12 . Known chronic conditions, ear infections, cardiac and gastrointestinal conditions and chest wall problems were excluded for the acute group (adapted from Smith, 1997: 9-12).

The sampling frame consisted of the patient registers from January 2001 till May 2001 for those clinics where diagnostic information and patient identification was possible from the register. Where this system was not in place, all clinic files were systematically drawn and checked; patients who met the criteria and who were seen from January 2001 onwards qualified for inclusion.

The sample sizes were proportional to the total number of patients seen for diabetes and for curative conditions at the respective clinics, based on statistics of the previous year.They were calculated to have $80 \%$ power to show a $20 \%$ difference in each quality indicator ( $50 \%$ vs. $70 \%$ ) at a $5 \%$ significance level, which led to a sample size of 300 per group.

The date of the last file drawn at each clinic differed slightly between clinics depending on how soon the proportional sample was reached for each of these facilities. The latest date was at the of May 2001.
For acute respiratory tract infections, emphasis was placed on the generic steps that are deemed essential in the management of an acute respiratory condition.

This approach did not define whether the history taking, clinical examination and management for each specific condition presented were performed correctly, but did examine whether they were adequately recorded.

The diagnostic variables examined were: recording of the main symptoms, information on previous medical history, allergy, habits or occupation, recording of general appearance, temperature, pulse, chest examination, diagnosis and further investigation. The number of drugs prescribed, antibiotic prescribing, referral and health education or advice were assessed as indicators of therapeutic steps.

The self-completed nurse questionnaires recorded their age, gender, home language, experience as a nurse and other qualifications or degrees. Nurses who had completed the training at the UFS were defined as "trained" and those who had not as "untrained".

Clinic variables were recorded by the investigators and related to the type of facility, the nurse to patient ratio, the staff categories present and the existence of special diabetic clinic 


\section{Reliability and validity}

The content validity of the measurement instruments for the records was based on the relevant literature (Daniels et al. January 2000: 55, Mash \& Levitt 1999: 124, Levitt et al.

\section{Results}

21 clinics were included in the final study (one mobile clinic had to be excluded because the relevant files could not be

\section{Table 3: Predictors of score for ARTI}

\begin{tabular}{lccc}
\hline Predictors & Coefficient & P-value & $95 \%$ C.I. \\
\hline Trained & 0.59 & 0.056 & $(-0.02,1.21)$ \\
Mobile vs. fixed & -1.27 & 0.001 & $(-1.96,-0.58)$ \\
Satellite vs. fixed & -0.74 & 0.037 & $(-1.43,-0.05)$ \\
No years curative PHC & 0.05 & 0.006 & $(0.02,0.09)$ \\
Other degree & 1.06 & 0.03 & $(0.12,2.00)$ \\
\hline
\end{tabular}

*Multiple linear regression, adjusted for intra-clinic clustering. Other variables examined were nurse:patient ratio, visiting doctor, no. years of nursing experience, no. enrolled or assistant nurses, other diploma and nurse age.

1997:1073-1075) and on the teaching materials of the diploma course in Health Assessment, Diagnosis and Treatment of the UFS.

They were piloted at one clinic and adjusted several times. It was beyond the scope of this study to test the validity of this instrument against the most important criterium of quality of care, namely improvement in the patients ' health status.

Reliability was assessed by testing the inter-observer agreement between the two researchers (GL and MR) on a 7\% convenience sample of the patient files and expressed as a kappa statistic. Test re-test reliability was not assessed.

The study was approved by the Ethics Committee of the Faculty of Health Sciences of the UFS.

\section{Statistical methods}

The analysis firstly consisted of descriptive tables with proportions and $95 \%$ confidence intervals. Chi-square tests or exact test were used to compare the proportions of those who did "the right thing" for both groups. Wilcoxon sum rank test and $\mathrm{t}$-test were used for the continuous variables.

For each condition, a score was calculated as the total number of relevant care items recorded in patients" notes. The maximum score attainable for each condition was 9 , with each item given equal weight. For ARTIs the following items were included in the score: main complaint, previous history, general appearance, temperature, pulse, chest examination, diagnosis, health education and further investigation. The diabetes score consisted of weight, blood pressure, any symptoms, diabetic symptoms, any clinical examination, foot examination, blood glucose test, urine test and health education. The independent influences of patient, nurse and clinic characteristics on scores were estimated using multiple linear regression (Stata Corporation 1999, Reference P-Z: 118-138). P-values and confidence intervals were adjusted for intra-clinic clustering of outcomes .

\section{Feedback and discussion}

Results of the audit were discussed with service providers and managers in a presentation session and a subsequent workshop. traced). All nurses except for one untrained nurse agreed to participate.

The final number of files obtained was 286 for diabetes and 293 for ARTIs.

Kappa results for inter-rater agreement were 0.88 (main complaint), 0.80 (general appearance) and 0.90 (chest exam) for the ARTIs and 1.0 (any symptoms) and 0.86 (any clinical exam) for diabetes.

\section{Baseline comparison of groups}

Patients managed by "trained" and "untrained" nurses had similar demographic characteristics (Table 1). The blood pressure and the glucose values were not significantly different between the two groups of diabetic patients.

\section{Arti}

Table 2 compares the items noted in the patient records by both groups of nurses. Overall, the recording of essential steps in patient management was poor. Most striking was the low percentage of patients who had their temperature and pulse taken ( $11 \%$ and $3 \%$ respectively) and the fact that only $28 \%$ of the patients had a diagnosis recorded, while $65 \%$ of the patients received an antibiotic.

On comparison of both groups, there was no statistically significant difference for any of the steps except for the recording of the main complaint, which was performed better by the trained nurses.

Multiple linear regression on the score (Table 3) increased the estimated effect of training. The coefficient in this table represents the difference in scores, adjusted for other variables in the model. Patients of trained nurses had a 0.59 ( -0.02 to 1.21$)$ points higher score on average, adjusting for all other influences on the score. Other variables, which were positively associated with the score, were the number of years the nurse had worked in curative primary health care $(+0.05$ per year $)$ and the acquisition of another nursing degree $(+1.06)$. The score decreased with 1.27 points for mobile vs. fixed clinics and with 0.74 points for satellite vs. fixed clinics. 


\section{Table 4: DIABETES: Proportion (\%) of patients that had items recorded}

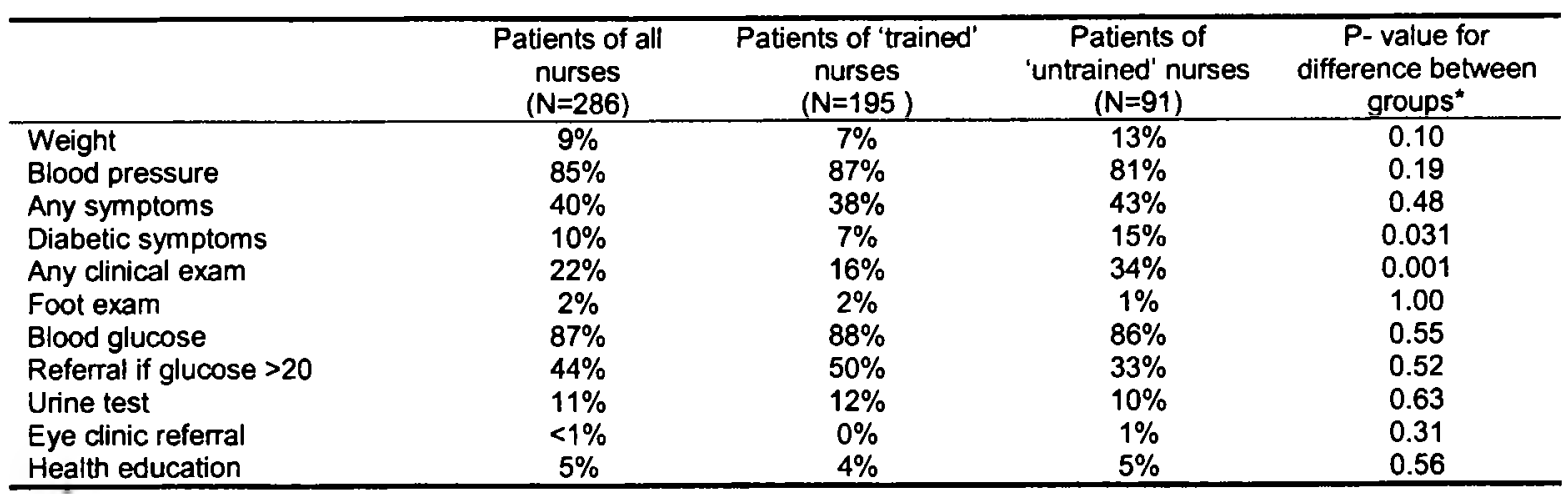

* $\chi^{2}$ test, Fisher exact for foot exam, eye clinic referral and health education.

\section{Table 5: Diabetes: predictors of score*}

\begin{tabular}{lccc}
\hline Predictors & Coefficient & P-value & $95 \%$ \\
\hline Trained & -0.19 & 0.47 & $(-0.74,0.35)$ \\
Combined vs. oral & -0.47 & 0.36 & $(-1.51,0.58)$ \\
Insulin vs. oral & 0.33 & 0.039 & $(0.02,0.64)$ \\
Mobile vs. fixed & 0.02 & 0.97 & $(-1,1.03)$ \\
Satellite vs. fixed & -1.05 & 0.001 & $(-1.65,-0.46)$ \\
No of enrolled/assistant nurses & 0.66 & 0.06 & $(-0.03,1.34)$ \\
\hline
\end{tabular}

*Multiple linear regression adjusted for intra-clinic clustering. Other variables examined are as for Table 3.

groups of nurses. Blood pressure and blood glucose tests were usually recorded $(85 \%$ and $87 \%$ ) but weight, diabetic symptoms, foot exam, urine test and eye clinic referral were seldom recorded. "Untrained" nurses scored significantly better for diabetic symptoms and clinical exam than did "trained" nurses. Table 5 shows the predictors of the score after multiple linear regression and adjusting for intra-clinic clustering. The only variables which were significantly and independently associated with the score were the number of enrolled or assistant nurses per clinic (increases the score with 0.66 points) and satellite vs. fixed clinics (-1.05). The score for insulin dependent patients was on average 0.55 points higher than for patients on oral treatment.

For both conditions nurse:patient ratio, visiting doctor at a clinic and years of experience as a nurse had no independent influence on the final score after adjustment for possible confounders.

In the workshop subsequent to the presentation of the results nurses highlighted lack of knowledge, bad habits, low commitment, shortage of equipment and the absence of standardized formats (for diabetes) as the main reasons for poor performance.

\section{Discussion}

The study found little evidence of patients being thoroughly assessed. additional degrees in nursing seems to play a positive role in the management of ARTIs. Enrolled and assistant nurses appear to contribute significantly to the quality of diabetes care. Nurses working in fixed clinics performed better than those working in satellite and mobile clinics .

\section{Comparison with other studies:}

Recording of diabetic complications was poor in our audit, which is consistent with the evaluation of primary diabetes care in Cape Town (Levitt et al. , 1997: 1073-1076). They found that out of a group of 243 patients no patients had a documented examination for retinopathy, only one patient had absent foot pulses recorded and 12 had proteinuria recorded. This was supported by the study of Mash and Levitt (1999:124) where visual acuity tests, fundoscopy, foot examination and proteinuria were all hardly recorded. Referral rates for patients with poor glucose control were also low.

The impact of a quality improvement cycle in the latter study yielded only a few positive results, which illustrates the difficulty of improving diabetes care.

Qualitative research in the Western Cape by Daniels et al. (Dec 2000:1209) demonstrated that 'the applications of guidelines in local settings is determined by the attitudes of health professionals to the development, dissemination and implementation of guidelines, as well as by health system factors and patient beliefs'. 


\section{Strengths and limitations of the study}

The main limitation of the study regarding its assessment of the training effectiveness is that this was not a randomised controlled trial. Trained nurses and their patients could therefore be systematically different, regardless of the training. We did however control for a wide range of possible confounding variables.

The results cannot be applied to patients who do not reside in the catchment area of a clinic and visit that clinic only occasionally. During the process of the retrieval of files it became apparent that most of the clinics had adopted an unwritten policy of seeing these "visitor" patients without opening files. The number of patients affected by this system was difficult to assess since most clinics did not have a detailed register that allowed for file identification, but was estimated to be more than a third of the patients for some clinics. Inclusion of these patients would have decreased the scores.

The high inter-rater agreement between the two researchers (one experienced and highly trained professional nurse and one medical doctor with a primary health care training background) indicates consistent interpretation of patients' records.

\section{Implications for policy and future research}

The estimated effect of the training was limited for acute respiratory tract infections and non-existent for diabetes. An emphasis shift is probably needed (e.g. stressing the importance of vital signs) as well as a critical analysis of the teaching methods.

A standardized format may be useful for managing diabetes. This suggestion was adopted by the nurses, who participated in this audit. Files should be made for all patients, whether they are visiting clients or not. Nurses could be provided with a personal set of basic equipment (blood pressure meter, stethoscope, and thermometer) since they reported that missing equipment contributed to the non-performance of certain basic diagnostic steps.

Enrolled nurses and assistant nurse appear to be valuable team members in reducing the workload of professional nurses since they perform essential routine tasks (e.g. taking of weight, blood pressure, and temperature).The poorer performance of satellite and mobile clinics needs further exploration, but may be due to facility constraints and lack of continuity in care.

Blood pressure levels and glucose values were similar for diabetic patients of trained and untrained nurses. They reflect the quality of the previous visit, which may have been done by another nurse. It is thus difficult to assess the impact of training on these indicators.

Future research should include a well-planned randomized controlled trial, which would allow for an independent evaluation of the effectiveness of formal PHC training.

\section{Acknowledgements}

We sincerely wish to thank the following people for their support: Dr A Hiemstra, Medical Officer of Health of the Mangaung municipality for initiating the research, staff nurse R. Motsohi and D. Glaun for their assistance with the retrieval of files and with the data input, all professional nurses and clinic managers of the Bloemfontein local authority clinics for their willingness to participate and Dr. D. Standert for giving background to the training course.

\section{References}

DANIELS, AR, PATEL, M, BIESMA, R, OTTEN, J,LEVITT, NS, STEYN, K, MARTELL RS, DICK, J 2000 : A structured record to implement the national guidelines for diabetes and hypertension care. South African medical journal. 90 (1) January 2000: 53-56.

DANIELS, AR, BIESMA, R,OTTEN,J,LEVITT,NS,STEYN, K, MARTELL, R, DICK, J 2000 : Ambivalence of primary health care professionals towards the

South African Guidelines for Hypertension and Diabetes. South African medical journal. 90 (12): December 2000: 1206-1211.

GOODMAN, RG, ZWARENSTEIN MF, ROBINSON II, LEVITT NS: Staff knowledge, attitudes and practices in public sector primary care of diabetes in Cape Town. South African medical iournal. 87 (3) March 1997: 305-309.

IRWIG, LM, PORTER, B, WILSON, 'IT), SAUNDERS, LD, WAGSTAFF,LA,LIESCH, N, REINACH,SG,MAKHAYA,MS, GEAR, JSS 1985: Clinical competence of pediatric primary health care nurses in Soweto. South African medical iournal. 67 January 1985: 92-95.

LEVITT, NS, BRADSHAW, D, ZWARENSTEIN, MF, BAWA, AA, MAPHUMOLO, S. 1997 : Audit of Public Sector Primary Diabetes Care in Cape Town, South Africa: High prevalence of Complications, Uncontrolled Hyperglycemia, and Hypertension. Diabetic Medicine, 14:1073-1077.

MASH, B, LEVITT, NS 1999 : Quality improvement in the care of people with diabetes in Khayelitsha, Cape Town. South African Familv Practice. 20(1) January 1999:123-125.

ROTHMANN,JC, GERBER,JJ, VENTER, OM,STEYN, HS, de K MONTEITH, JL 2000 : Primary care drug therapy training: the solution for PHC nurses? Curationis. 23(1) March 2000:43-52.

SMITH, S 1997: An Introduction to the curative aspects of Primary Health Care. Glenstantia: S. Smith.

STATA CORPORATION 1999 : Stata Reference Manuals. Release 6. Texas, College Station: Stata Press. 